\title{
CALR, JAK2 and MPL Genes Mutations in Myeloproliferative Neoplasms, Single Center Experience
}

\section{Myeloproliferatif Neoplazilerde CALR, JAK2 ve MPL Gen Mutasyonlarının Sıklığının ve Birlikteliğinin Değerlendirilmesi; Tek Merkez Deneyimi}

\author{
Taha BAHSİ ${ }^{1}$, Tuğçe Nur Yiğenoğlu ${ }^{2}$ \\ ${ }^{1}$ Sbü Abdurrahman Yurtaslan Ankara Onkoloji Eğitim Ve Araştırma Hastanesi, Tıbbi Genetik \\ ${ }^{2}$ Sbü Abdurrahman Yurtaslan Ankara Onkoloji Eğitim Ve Araştırma Hastanesi, Hematoloji
}

Dergiye Ulaşma Tarihi: 17/10/2019 Dergiye Kabul Tarihi: 23/10/2019 Doi: 10.5505/aot.2019.03521

\section{ÖZET}

GíRIŞ ve AMAÇ: Philedelphia negatif $\mathrm{Ph}(-)$ myeloproliferatif neoplazilerin (MPN) tanısında klinik ve laboratuvar bulgularının yanında genetik testler çok önemlidir. Bunlar arasında JAK2 genindeki V617F mutasyonu en sık görülen genomik varyasyondur. Bunlara ek olarak MPL geninde W515L/K mutasyonunun ve CALR genindeki mutasyonların araştırılması da önem taşımaktadır. Çalışmamızda, MPN tanısı almış olan hastalarda retrospektif olarak JAK2 V617F, MPL W515L/K ve CALR mutasyon dağılımı ve sıklığ araştırıldı.

YÖNTEM ve GEREÇLER: MPN grubu hastalık tanısı ile başvuran 41 hastanın JAK2 V617 mutasyonu, MPL W515L/K mutasyonu ve CALR gen mutasyonlarına yönelik test sonuçları retrospektif olarak incelendi. Genetik parametreler real-time PCR cihazı ile analiz edildi.

BULGULAR: Tüm hastalarda JAK2 V617F mutasyon sıklığ1 \%36, CALR mutasyon sıklığ \%17 olarak bulunurken, MPL W515L/K mutasyonu hiçbir hastada gözlenmedi. MPN'nin alt gruplarını oluşturan; polisitemi vera, esansiyel trombositoz ve primer myelofibrozis gruplarında JAK2 V617F mutasyon siklığ sırasıly \%67, $\% 33$ ve $\% 25$ olarak bulunurken; CALR mutasyon sıklığı ise $\% 8, \% 29$ ve $\% 8$ olarak bulundu. MPL W515L/K ise hiçbir grupta gözlenmedi.

TARTIŞMA ve SONUÇ: Daha önce yapılan çalışmalarda Ph(-) MPN grubu hastalıklarda JAK2 V617F, MPL W515L/K ve CALR mutasyon sıklığının çok geniş aralıklarda olduğu bildirilmiştir. Sonuç olarak, mutasyonların dağılımında etnisite ve epigenetik faktörlerin yanı sıra sigara, rakım gibi çevresel faktörlerin de etkisinin olduğunu düşünülmektedir.

Anahtar Kelimeler: Myeloproliferatif Neoplazi, JAK2, MPL, CALR

\section{ABSTRACT}

INTRODUCTION: Genetic tests are very important for the diagnosis of Philedelphia negative myeloproliferative neoplasms (MPN), in addition to clinical findings and laboratory results. JAK2 V617F mutation is the most common genomic variaton among these group of diseases. Otherwise, analysis of $\mathrm{W} 515 \mathrm{~L} / \mathrm{K}$ mutation in MPL gene and CALR gene mutations is crucial. In this study, prevalence of JAK2 V617F, MPL W515L/K mutations and, spectrum and prevalence of CALR gene mutations were investigated in MPN patients. METHODS: Genetic test results of JAK2 V617 mutation, MPL W515L/K mutation and CALR gene mutations of 41 MPN patients were analysed, retrospectively. Genetic parameters were performed with real-time PCR.

RESULTS: While the frequency of JAK2 V617F mutation was 36\% and CALR mutation was $17 \%$ in all patients, MPL W515L/K mutation was not detected in any patient. In terms of subgroups of MPN; in polycythemia vera, essential thrombocytosis and primary myelofibrosis groups, the incidence of JAK2 V617F mutation was $67 \%, 33 \%$ and $25 \%$, respectively; and the incidence of CALR mutation was $8 \%, 29 \%$ and $8 \%$, respectively. MPL W515L/K was absent in all groups.

DISCUSSION AND CONCLUSION: Previous studies have reported that the frequency of JAK2 V617F, MPL W515L/K and CALR mutations in Ph (-) MPN group diseases is very variable. As conclusion, it is thought that environmental factors such as smoking and altitude have an effect besides epigenetic factors such as ethnicity in distribution of mutations.

Keywords: Myeloproliferative Neoplasm, JAK2, MPL, CALR 


\section{GíRiș}

Myeloproliferatifneoplazmlar (MNP); myeloid serinin bir ya da birden fazla hücre tipinin kontrolsüz çoğalımı ile karakterize olanklonalhematopoeitik kök hücre hastalı̆̆ıdır. MNP grubu hastalıklar; kronik myelositer lösemi (KML), polisitemivera (PV), esansiyeltrombositopeni (ES) ve primermyelofibrozisdir (PMF) (1). KML'de 'Phieldelphia Kromozomu' adı verilen 9. ve 22. Kromozomlar arasinda kitranslokasyon sonucu oluşan bir füzyon geni mevcuttur ve bu hastalık için sitogenetik bir belirteçtir (2). Bundan dolayı KML'yephiledelphia pozitif MPN'de denilmektedir. Philedelphia negatif$\mathrm{Ph}(-)$ veya diğer adıyla $B C R-A B L$ negatifMPN'ler ise;polisitemivera (PV), esansiyeltrombositopeni $\quad(E S) \quad$ ve primermyelofibrozisdir (PMF) (1,3).Dünya Sağlık Örgütü $2016 \quad$ y1lında myeloproliferatifneoplazilerin tan1 ve tedavi kılavuzunu yeniden düzenlemiştir ve günümüzde de halen bu k1lavuz kullanılmaktadır (4,5). Bu kılavuza göre klinik ve rutin laboratuvar bulguları ile myeloproliferatifneoplazi düşünülen bir hastada tanıyı desteklemek için bazı moleküler testlerin yap1lmas1 gerekmektedir $(4,5)$. İlk olarak JAK2 V617F mutasyon araştırılması yapılmas1 önemlidir $(4,5)$. JAK2 V617F mutasyonu pozitifse PV, ET veya PMF tanıs1 yüksek olasılıklıdır ve DSÖ kriterlerine göre MPN alt tipi belirlenir $(4,5)$. JAK2 V617F mutasyonu negatif çıkması ve klinik bulguların MPN'yi işaret etmesi durumunda ise CALR, $M P L$ ve $J A K 2$ ekzon 12 mutasyon araştırılmas1 önerilmektedir $(4,5)$.

JAK2 V617F mutasyonu PV'li hastaların yaklaşık \%95'inde, ET veya PMF'li hastaların \%50-60'ında pozitiftir (6). JAK2 ekzon12 mutasyonu PV'li hastaların az bir k1smında saptanmakla birlikte JAK2 mutasyonu saptanmayan ET veya PMF'li hastaların yaklaşık \%5-10'unda $M P L$ gen mutasyonu saptanmaktadır (6).Böylece hemen hemen tüm PV'li hastalarda JAK2 mutasyonu bulunurken, ET ve PMF'li hastaların yaklaşı üçte birinde $J A K 2$ veya $M P L$ genlerinde herhangi bir mutasyon bulunmamaktadır. İşte $J A K 2$ ve $M P L$ genlerinde mutasyon bulunmayan $\mathrm{Ph}(-)$ MPN hastalarına CALR mutasyon araştırılması önerilmektedir $(7,8)$.

CALR geni 19p13.2 de lokalize 9 ekzondan oluşan bir gendir (9). CALR proteinin en önemli fonksiyonu endoplazmikretikulumdaCa ${ }^{++}$bağlayıc1 bir şaperon görevi yapmasıdır (10).CALR geninde meydana gelen mutasyonlar birçok hücresel fonksiyonun kaybına neden olmaktadır; bunların en önemlilerinden olanı daapoptotik hücrelerin ve kanser hücrelerinin fagositozunun azalmasıdır (11).

CALR mutasyonlarının hemen hemen tamamı 9. ekzondadır (12) . En sik görülen mutasyonlar ise; c.1092_1143del52 ve c.1154_1155insTTGCT'dir. CALR c.1092_1143del52 mutasyonuna Tip1, CALRc.1154_1155insTTGCT mutasyonuna ise Tip2 ad1 verilmektedir. Tip1'de 52 bazlık (52 bç) bir delesyon tip2'de ise 5 bazlık (5 bç) insersiyon mevcuttur (12).Bu çalışmada; Türk toplumunda PV, ET ve PMF tanil1 hastalardaJAK2 V617F, MPL W515L/K veCALR mutasyon dağılımını araştırdık.JAK2 V617F ve $M P L W 515 \mathrm{~L} / \mathrm{K}$ genleri ile ilgili çalışma sayısıCALR mutasyon sıklığı ile ilgili çalışmalara göre daha fazladır. Yaptığımız çalışma ile hastanemize başvuran Türk populasyonuna ait hastalarda ki CALR mutasyon sıklığını ve $C A L R$ mutasyonu ile JAK2 V617F ve MPL W515L/K mutasyon sıklı̆̆ını ve birlikteliğini göstermeyi hedefledik.

\section{MATERYAL METOD}

Kliniğimize ET, PV ve PMF ön tanısı ile konsülte edilen 41erişkin hastaya JAK2 V617F, MPL W515L/K, CALR geni Tip1 ve Tip2 mutasyon araştırılması yapıldı. Hastaların 17 tanesi ET, 12 tanesi PMF ve 12 
tanesi de PV klinik tanısı ile başvurmuştu. Hastalardan ilk olarak periferik kandan DNA eldesi yap1ld. Daha sonra JAK2 V617F mutasyon analizi yapıldı. Bunun için Qiagenreal time PCR kiti kullanıldı. JAK2 V617F negatif çıan hasta grubuna ise ipsogen $M P L \mathrm{~W} 515 \mathrm{~L} / \mathrm{K}$ ve $C A L R$ Tip1 ve Tip2 real time PCR kitleri kullanıldı. Her üç kit kullanılarak yapılan çalışmalar Qiagene RotorGene Real Time PCR cihazı ile gerçekleştirildi. Elde edilen sonuçlar RotorGene Assay Manager v2.1 Gama Plug-in analiz programı ile analiz edildi.

\section{BULGULAR}

Yapılan analizler sonrasında; toplamda ki 41 hastanın 15'inde (\%36) JAK2 V617F, 7'sinde (\%17) CALRmutasyonu tespit edildi. Hastaların hiçbirisinde $M P L$ W515L/K mutasyonu tespit edilmedi.JAK2 V617F mutasyonu tespit edilen hastaların 8 tanesi PV, 3 tanesi PMF, 4 tanesi ise ET klinik tanısına sahipti. CALR mutasyonu tespit edilen hastaların 5 tanesi ET, 1 tanesi PV ve 1 tanesi de PMF tanısina sahipti. Bir hasta da Tip2 mutasyon tespit edildi ve bu hasta ET tanısına sahipti. Diğer 6 hastada ise Tip1 mutasyon belirlendi (Tablo 1).JAK2 V617F mutasyonu PV'li hastaların \%67'sinde, ET'li hastaların \%33'ünde ve PMF'li hastaların \%25'inde görüldü. CALR mutasyonu ise ET'li hastaların \%29'unda, PMF'li ve PV'li hastaların ise $\% 8$ 'inde görüldü (Tablo 2).

\section{TARTIŞMA ve SONUÇ}

Myeloproliferatif neoplaziler hematopoeitik sistemin önemli bir hastalı grubudur. Kronik myelositer lösemi philedelphia pozitif MPN olarak adlandırılırken BCR-ABL translokasyonu görülmeyen polisitemi vera, esansiyel trombositemi ve primer myelofibrozis ise philedelphia negatif MPN olarak adlandırılmaktadır (1,3). Bu hastalıklarda tanı için ilk basamak genetik test $J A K 2$ V617F mutasyon analizidir (13).
Tablo 1. Genel hasta grubunda mutasyonların dağılımı

\begin{tabular}{|c|c|c|c|}
\hline Hasta & Tanısı & $J A K 2 \mathrm{V617F}$ & CALR \\
\hline Hasta 1 & ET & Mutasyon yok & Tip2 pozitif \\
\hline Hasta 2 & MF & Mutasyon yok & Mutasyon yok \\
\hline Hasta 3 & ET & Mutasyon yok & Mutasyon yok \\
\hline Hasta 4 & PRV & $\% 73$ pozitif & Mutasyon yok \\
\hline Hasta 5 & PRV & $\% 91$ pozitif & Mutasyon yok \\
\hline Hasta 6 & ET & Mutasyon yok & Mutasyon yok \\
\hline Hasta 7 & MF & Mutasyon yok & Mutasyon yok \\
\hline Hasta 8 & PRV & Mutasyon yok & Mutasyon yok \\
\hline Hasta 9 & MF & $\% 89$ pozitif & Mutasyon yok \\
\hline Hasta 10 & MF & Mutasyon yok & Mutasyon yok \\
\hline Hasta 11 & MF & $\% 71$ pozitif & Mutasyon yok \\
\hline Hasta 12 & $\mathrm{MF}$ & Mutasyon yok & Mutasyon yok \\
\hline Hasta 13 & PRV & $\% 11$ pozitif & Mutasyon yok \\
\hline Hasta 14 & ET & $\% 94$ pozitif & Mutasyon yok \\
\hline Hasta 15 & ET & Mutasyon yok & Tip1 pozitif \\
\hline Hasta 16 & ET & Mutasyon yok & Mutasyon yok \\
\hline Hasta 17 & PRV & $\% 23$ pozitif & Mutasyon yok \\
\hline Hasta 18 & ET & Mutasyon yok & Mutasyon yok \\
\hline Hasta 19 & PRV & Mutasyon yok & Tip1 pozitif \\
\hline Hasta 20 & ET & $\% 22$ pozitif & Mutasyon yok \\
\hline Hasta 21 & PRV & $\% 94$ pozitif & Mutasyon yok \\
\hline Hasta 22 & ET & Mutasyon yok & Tip1 pozitif \\
\hline Hasta 23 & ET & Mutasyon yok & Mutasyon yok \\
\hline Hasta 24 & PRV & $\% 83$ pozitif & Mutasyon yok \\
\hline Hasta 25 & ET & Mutasyon yok & Mutasyon yok \\
\hline Hasta 26 & ET & $\% 86$ pozitif & Mutasyon yok \\
\hline Hasta 27 & MF & $\% 28$ pozitif & Mutasyon yok \\
\hline Hasta 28 & ET & Mutasyon yok & Mutasyon yok \\
\hline Hasta 29 & ET & Mutasyon yok & Mutasyon yok \\
\hline Hasta 30 & PRV & Mutasyon yok & Mutasyon yok \\
\hline Hasta 31 & ET & $\% 9$ pozitif & Mutasyon yok \\
\hline Hasta 32 & ET & Mutasyon yok & Tip1 pozitif \\
\hline Hasta 33 & $\mathrm{MF}$ & Mutasyon yok & Mutasyon yok \\
\hline Hasta 34 & PRV & $\% 32$ pozitif & Mutasyon yok \\
\hline Hasta 35 & MF & Mutasyon yok & Mutasyon yok \\
\hline Hasta 36 & PRV & $\% 23$ pozitif & Mutasyon yok \\
\hline Hasta 37 & PRV & Mutasyon yok & Mutasyon yok \\
\hline Hasta 38 & MF & Mutasyon yok & Mutasyon yok \\
\hline Hasta 39 & $\mathrm{MF}$ & Mutasyon yok & Mutasyon yok \\
\hline Hasta 40 & ET & Mutasyon yok & Tip1 pozitif \\
\hline Hasta 41 & MF & Mutasyon yok & Tip1 pozitif \\
\hline
\end{tabular}

Tablo 2. Mutasyonların hastalıklara göre görülme yüzdesi

\begin{tabular}{|l|l|l|}
\hline Hastalık & $\begin{array}{l}\text { JAK2V617F } \\
\text { görülme yüzdesi }\end{array}$ & $\begin{array}{l}\text { CALR görülme } \\
\text { yüzdesi }\end{array}$ \\
\hline PV & $\% 67$ & $\% 8$ \\
\hline ET & $\% 33$ & $\% 29$ \\
\hline PMF & $\% 25$ & $\% 8$ \\
\hline
\end{tabular}

PV'li hastaların \%95'inde JAK2 V617F mutasyonu pozitif beklenmektedir (6). Bizim çalışmamızda PV'li hastaların \%67'sinde JAK2 V617F mutasyonu pozitif saptanmıştır. $\mathrm{Bu}$ durumun hemoglobin düzeyini yükseltensekonder sebeplere bağl1 
olabileceğini düşünmekteyiz. Bunların başında da; ülkemizde sigara içme oranının oldukça fazla olması ve ülkemizin ortalama rakım seviyesinin dünya ortalamasına göre yüksek olmasından kaynaklandığını düşünmekteyiz. Ayrica 2016 y1lına kadar DSÖ tan1 kriterlerinde PV tanısı için hemoglobin düzeyi erkeklerde $18.5 \mathrm{~g} / \mathrm{dl}$ kadınlarda ise $16.5 \mathrm{~g} / \mathrm{dl}$ üzerinde olması şeklindeydi (14). 2016 yılında yayımlanan kılavuza göre ise bu değerler erkeklerde $16.5 \mathrm{~g} / \mathrm{dl}$ kadınlarda ise $16 \mathrm{~g} / \mathrm{dl}$ olarak uygulanmaya başlandı $(4,5)$. Dolayısıyla sigara içme oranının ve ortalama rakım değerinin dünya ortalamalarına göre oldukça fazla olduğu ülkemizde rölatif hemoglobin yüksekliğine bağlı klinik ön tanı nedeniyle $J A K 2 \mathrm{~V} 617 \mathrm{~F}$ mutasyon oranının literatürün altında olduğunu düşünüyoruz.ET'li hasta grubunda ise $J A K 2$ V617F mutasyon oran1 $\% 33$ olarak saptandı. Genel olarak ET'li hastalarda $J A K 2$ V617F mutasyon oran $\% 50$ 60 arasında beklenirken literatürde ki bazı çalışmalarda çok geniş bir aralıkta mutasyon görülme oranı bildirilmiştir (15). Carobbio ve ark. yaptıkları çalışmada ET tanısı almış olan hastaları çeşitli gruplara ayırdıklarında JAK2 V617F mutasyon görülme oranının \%27-\%77 arasında değiştiğini bildirmişlerdir (16). Bu çalışmada ki sonuçlar bizim çalışmamızda görülen \%33'lük JAK2 V617F pozitiflik oranını desteklemektedir.PMF'li hasta grubunda JAK2 mutasyon oran1 \%25 olarak saptand. PMF'li hastalarda genel olarak JAK2 mutasyon oranı $\% 50$ civarında beklenmekle birlikte yapılan çalışmalarda farklı sonuçlar ortaya çıkmıştır (15). Ebid ve ark. yaptıkları çalışmada myelofibrozisli hastalarda JAK2 mutasyon oranını \%12.5 olarak bildirmişlerdir (17). Yine Jaradat ve ark. ise yaptıkları çalışmada PMF'li hastalarda JAK2 V617F mutasyon oranını \%45 olarak bildirmişlerdir (18).Bütün bu literatür verilerinin dışında Ochoa ve ark. yaptıkları meta-analiz çalışmasında JAK2 V617F mutasyon oranını PV'li grupta \%46.7-100 aralığında, ET'li hasta grubunda \%31.3-72.1 aralı̆̆ında ve PMF'li hasta grubunda ise \%25-85.7 aralığında olduğunu bildirmişlerdir (15). Bu meta-analiz çalışmasında da görüldüğü üzere $J A K 2 \mathrm{~V} 617 \mathrm{~F}$ mutasyon oranı $\mathrm{Ph}(-)$ MPN grubunda büyük değişkenlikler göstermektedir. Bizim çalışmamızda elde ettiğimiz sonuçlarda diğerliteratür verileriyle uyumludur.

Çalışmamızda hiçbir hasta grubunda MPL W515L/K mutasyonu saptamadik. Yine Ochoa ve ark. yaptıkları meta-analiz çalışmasında belirtildiği üzere 14 farklı çalışmada $M P L \mathrm{~W} 515 \mathrm{~L} / \mathrm{K}$ mutasyon görülme sıklığl; PV'da \%0, ET'de \%0.9-12.5 ve PMF'de ise \%0-17.1 olarak belirtilmiştir (15). Bizim çalışmamızın da bu literatür verileri ile uyumlu olduğu görülmektedir.

Çalışmamıda CALR mutasyon oranları incelendiğinde PV'live PMF'lihasta grubundaCALR mutasyon oran1 \%8 olarak görüldü. ET'li hasta grubunda ise $C A L R$ mutasyon oranını \%29 olarak saptadık. Ochoa ve ark. yaptıkları meta-analiz çalışmasında benzer sonuçlar ortaya koyulmuştur (15). Dolayısıyla çalışmamızda $k i$ CALR mutsyon oranları da literatür verileri ile benzerdir.

$\mathrm{Ph}(-)$ neoplazilerin tanısı halen klinik bulgular, biyokimyasal ve hematolojik laboratuvar bulguları ve genetik testler ile konulmaktadır. Elbette hepsinin ayrı bir önemi olmakla birlikte özellikle genotipik değişikliklerden JAK2 V617F değişimi en sık gözlenmektedir. Dolayısıyla JAK2 V617F mutasyon araştırılması genetik testler içinden birinci basamak olarak değerlendirilmektedir. $M P L \mathrm{~W} 515 \mathrm{~L} / \mathrm{K}$ ve $C A L R$ mutasyon siklığının daha az oranda görülmesi ise tanıdan çok belki prognoz değerlendirmede önemli olacaktır.

Ayrıca her üç hastalık grubu için bu üç farklı genotipik değişim sıklığının oldukça farklı oran aralıklarında görülmesinin sebebi olarak; farklı etnisite faktörleri ve özellikle PV için sigara, rakım gibi çevresel faktörlere bağlı rölatif $\mathrm{Hb}$ düzeyi yüksekliğinin rol oynadığını düşünmekteyiz. Bu çevresel faktörlerin dışında henüz bilinmeyen modifiyeedici genler ve 
epigenetik faktörlerde bu farklilıklara sebep olabilir.

\section{Çıkar Çatışması: Yok}

\section{REFERANSLAR}

1. Rumi E, Cazzola M. Diagnosis, risk stratification, and response evaluation in classical myeloproliferative neoplasms. Blood. 2017;129:680-691

2. Press RD, Love Z, Tronnes AA et al. BCR-ABL mRNA levels at and after the time of a complete cytogenetic response (CCR) predict the duration of CCR in imatinib mesylate-treated patients with CML. Blood. 2006;107:4250-4256

3. Van Etten RA, Koschmieder S, Delhommeau F et al. The $\mathrm{Ph}$-positive and Ph-negative myeloproliferative neoplasms: some topical pre-clinical and clinical issues. Haematologica. 2011;96:590-601

4. Barbui $\mathrm{T}$, Thiele $\mathrm{J}$, Gisslinger $\mathrm{H}$ et al. The $2016 \mathrm{WHO}$ classification and diagnostic criteria for myeloproliferative neoplasms: document summary and in depth discussion. Blood Cancer Journal. 2018;8:1-11

5. Arber DA, Orazi A, Hasserjian R et al.The 2016 revisiontothe World Health Organization classification of myeloid neoplasms and acute leukemia. Blood. 2016;127:2391-2405

6. Tefferi A, Vainchenker W. Myeloproliferative Neoplasms: Molecular Pathophysiology, Essential Clinical Understanding, and Treatment Strategies. J Clin Oncol. 2011;29:573-582

7. Klampfil T, Gisslinger H, Harutyunyan AS et al. Somatic mutations of calreticulin in myeloproliferative neoplasms. N Eng J Med. 2013;369:2379-2390

8. Nangalia J, Massie CE, Baxter EJ. Somatic CALR Mutations in Myeloproliferative Neoplasms with Nonmutated JAK2. N Eng J Med. 2013;369:2391-2405
9. Stein $\mathrm{H}$, Bob R, Erck $\mathrm{C}$ et al. A new monoclonal antibody (CAL2) detects Calretuculin mutations in formalin-fixed and paraffin-embedded bone marrow biopsies. Leukemia. 2016;30:131-135

10. Guglielmelli P, Nangalia J, Green AR, Vannuchi AM. CALR mutations in myeloproliferative neoplasms: Hidden behind the reticuum. AJH. 2014;89:453-456

11. Obeid M, Tesniere A, Ghiringhelli $F$ et al. Calreticulin exposure dictates the immunogenicity of cancer cell death. Nature Medicine. 2007;13:54-61

12. Giannopoulos A, Rougkala N, Loupis $T$ et al. Detection of CALR Mutations Using High Resolution Melting Curve Analysis (HRMA); Application on a Large Cohort of Greek ET and MF Patients. 2019;11:1-7

13. Tefferi A, Noel P, Hanson CA. Uses and Abuses of JAK2 and MPL Mutation Tests

İn Myeloproliferative Neoplasms. 2011;13:461-466

14. Tefferi A, Thiele J, Vardiman JW. Uses and Abuses of JAK2 and MPL Mutation Tests

In Myeloproliferative Neoplasms. Cancer. 2009;115:3842-3847

15. Ochoa MM, Toro PAA, Arias JAC. Systematization of analytical studies of polycythemia vera, essential thrombocythemia and primary myelofibrosis, and a metaanalysis of the frequency of JAK2, CALR and MPL mutations: 2000-2018. BMC Cancer. 2019;590:1-15

16. Carobbio A, Finazzi G, Antonioli $\mathrm{E}$ et al. Thrombocytosis and leukocytosis interactionin vascular complications of essential thrombocythemia. Blood. 2018;112:3135-3137

17. Ebid GT, Ghareeb M, Salaheldin O, Kamel MM. Prevalence of the frequency of JAK2 (V617F) mutation in different myeloproliferative disorders in Egyptian patients. Int J Clin Exp Pathol 2015;8(9):11555-11559

18. Jaradat SA, Khasawneh $R$, Kamal $N$ et al. Analysis of JAK2V617F mutationin Jordanian patients with myeloproliferative neoplasms. Hematol Oncol Stem Cell Ther. 2015;8(4):160-166 